\title{
Review
}

\section{Monitoring the impacts of trade agreements on food environments}

\author{
S. Friel"\#, L. Hattersley"\#, W. Snowdon",3\#, A.-M. Thow ${ }^{4 \#}$, T. Lobstein ${ }^{5,6 \#}$, D. Sanders ${ }^{7 \#, ~ S . ~ B a r q u e r a ~}{ }^{8 \#}$,

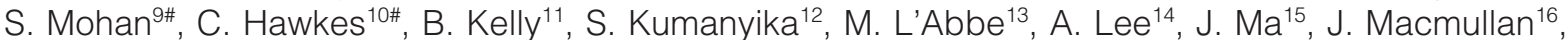 \\ C. Monteiro ${ }^{17}$, B. Neal ${ }^{18}$, M. Rayner ${ }^{19}$, G. Sacks ${ }^{3}$, B. Swinburn ${ }^{3,20}$, S. Vandevijvere ${ }^{20}$ and C. Walker ${ }^{21}$ \\ for INFORMAS^
}

\begin{abstract}
${ }^{1}$ National Centre for Epidemiology and Population Health, Australian National University, Canberra, Australian Capital Territory, Australia; ${ }^{2}$ Pacific Research Centre for the Prevention of Obesity and Non-Communicable Diseases (C-POND), Suva, Fiji; ${ }^{3} \mathrm{WHO}$ Collaborating Centre for Obesity Prevention, Deakin University, Melbourne, Victoria, Australia; ${ }^{4}$ Menzies Centre for Health Policy, University of Sydney, Sydney, New South Wales, Australia; ${ }^{5}$ International Association for the Study of Obesity, London, UK; ${ }^{6}$ Public Health Advocacy Institute of Western Australia, Curtin University, Perth, Western Australia, Australia; ${ }^{7}$ School of Public Health, University of the Western Cape, Cape Town, South Africa; ${ }^{8}$ National Institute of Public Health, Mexico City, Mexico; ${ }^{9}$ Public Health Foundation of India, New Delhi, India; ${ }^{10}$ World Cancer Research Fund, London, UK; ${ }^{11}$ School of Health and Society, University of Wollongong, Wollongong, New South Wales, Australia; ${ }^{12}$ Perelman School of Medicine, University of Pennsylvania, Philadelphia, Pennsylvania, USA; ${ }^{13}$ Department of Nutritional Sciences, University of Toronto, Toronto, Ontario, Canada; ${ }^{14} \mathrm{Sch}$ ool of Public Health and Social Work and School of Exercise and Nutrition Sciences, Queensland University of Technology, Brisbane, Queensland, Australia; ${ }^{15} \mathrm{Chinese}$ Center for Disease Control and Prevention (CCDC), Beijing, China; ${ }^{16}$ Consumers International, London, UK; ${ }^{17}$ School of Public Health, University of Sao Paulo, Sao Paulo, Brazil; ${ }^{18}$ The George Institute, Sydney, New South Wales, Australia; ${ }^{19}$ British Heart Foundation Health Promotion Research Group, University of Oxford, Oxford, UK; ${ }^{20}$ School of Population Health, University of Auckland, Auckland, New Zealand; ${ }^{21}$ Global Alliance for Improved Nutrition (GAIN) Geneva, Switzerland
\end{abstract}

\section{Summary}

The liberalization of international trade and foreign direct investment through multilateral, regional and bilateral agreements has had profound implications for the structure and nature of food systems, and therefore, for the availability, nutritional quality, accessibility, price and promotion of foods in different locations. Public health attention has only relatively recently turned to the links between trade and investment agreements, diets and health, and there is currently no systematic monitoring of this area. This paper reviews the available evidence on the links between trade agreements, food environments and diets from an obesity and non-communicable disease (NCD) perspective. Based on the key issues identified through the review, the paper outlines an approach for monitoring the potential impact of trade agreements on food environments and obesity/NCD risks. The proposed monitoring approach encompasses a set of guiding principles, recommended procedures for data collection and analysis, and quantifiable 'minimal', 'expanded' and 'optimal' measurement indicators to be tailored to national priorities, capacity and resources. Formal risk assessment processes of existing and evolving trade and investment agreements, which focus on their impacts on food environments will help inform the development of healthy trade policy, strengthen domestic nutrition and health policy space and ultimately protect population nutrition.

Keywords: INFORMAS, non-communicable diseases, obesity, trade agreements.

obesity reviews (2013) 14 (Suppl. 1), 120-134

Address for correspondence: S Friel, National Centre for Epidemiology and Population Health, Mills Road, The Australian National University,

Canberra, ACT 0200, Australia.

E-mail: sharon.frie|@anu.edu.au

"Members of the writing group for this manuscript, listed in order of their contribution to the writing of the manuscript.

ANFORMAS is the International Network for Food and Obesity/non-communicable diseases Research, Monitoring and Action Support. All authors who are not members of the writing group are listed in alphabetical order, and contributed to the development of the key concepts and principles discussed in this manuscript as part of the first formal meeting of INFORMAS from 19 to 23 November 2012 at Bellagio, Italy. 


\section{Introduction}

Food trade is a key component of global, regional and domestic food systems. From a population nutrition perspective, the liberalization of international trade and foreign direct investment (FDI) (see Table 1 for definition of trade-related terminology) has brought about three important changes to food systems: opening of domestic markets towards international food trade and FDI; subsequent entry of transnational food corporations (TFCs) and their global market expansion; and global food advertising (1). These three changes affect population diets, and raise concerns about obesity and non-communicable diseases (NCDs), by altering the availability, nutritional quality, price and promotion of foods in different locations, i.e. consumer food environments (1-6).

A key mechanism of trade liberalization is the negotiation of international trade and investment agreements and treaties (hereafter collectively referred to as trade agreements), either bilaterally, regionally or multilaterally (6). The first international trade agreements to forefront food and agriculture as trade concerns were the eight multilateral agreements (Box 1) signed in 1995 with the completion of the Uruguay round of trade talks and the establishment of the World Trade Organization (WTO).

Together, these agreements expanded the focus of previous trade agreements from trade in goods to include trade in services, intellectual property (IP) and investment. They outlined commitments by member countries to reduce agricultural tariffs, export subsidies and domestic supports, to remove or amend national regulations and standards, which create barriers to trade, to harmonize standards relating to animal, plant and human health hazards arising from trade, to implement measures to liberalize trade in services, to grant minimum protection of IP rights for investors and to conduct open competitive government procurement, as well as procedures for resolving trade disputes.

In the two decades since these agreements came into force, demands have risen for a new generation of international agreements and rules to facilitate closer economic relations and supply chain integration, open markets for trade in services, remove restrictions on FDI and increase protection of investor IP rights. With the fourth (Doha) round of WTO talks effectively reaching stalemate, bilateral and regional trade agreements (RTAs), customs unions, investment treaties and economic integration agreements have proliferated. These trade agreements differ from the WTO agreements in a number of important ways. They apply exceptions to the WTO's founding principle of nondiscrimination by offering preferences to specific countries and discriminating against 'non-members'. They tend to intensify and extend commitments already made by WTO member countries (referred to as WTO-plus obligations).
They frequently incorporate qualitatively new provisions relating to subjects that lie outside the WTO mandate, such as environment, labour, competition policy, government procurement, investment and IP. These so-called 'WTOextra' commitments are not necessarily directly traderelated, and are referred to as 'behind-the-border' concerns since they are domestic public policy issues (7-9). Many countries are members of multiple bilateral or regional trade and/or investment agreement in addition to the WTO, creating a web of overlapping trade agreements, each with different sets of rules, inclusions and exclusions, which coexist alongside WTO regulations $(8,10)$.

In theory, trade liberalization has the potential to improve economic growth, help reduce poverty and raise living standards through increasing export opportunities and access to overseas markets, attracting lower cost imports and inward FDI, and extending the spread of technological and medical advances (11-13). All of these have the potential to benefit health. Trade also has the potential to benefit the nutritional status of populations by improving food availability, accessibility and affordability. However, the impacts of trade liberalization policies are strongly mediated by regional, national and local contexts, and there is evidence that trade liberalization has exacerbated inequalities between regions, countries and social groups, including the uneven development of new dietary habits and dietary outcomes, and contributed to the global burden of undernutrition, obesity and non-communicable diseases (NCDs) (1,5,6,14-22).

Public health attention has only relatively recently turned to the links between trade agreements, food environments, diets and health $(21,23)$. There is currently no comprehensive, systematic monitoring of new and existing trade agreements for their impacts on food environments with which to inform the development of effective, coherent policy approaches to improve diets and reduce the global burden of obesity and NCDs. This paper outlines the monitoring framework for the trade and investment module of the International Network for Food and Obesity/NCDs Research, Monitoring and Action Support (INFORMAS). INFORMAS is a global network of public-interest organizations and researchers that aims to monitor, benchmark and support public and private sector actions to create healthy food environments and reduce obesity, NCDs and their related inequalities (24). This module seeks to address the research question, 'What are the impacts of trade agreements on the healthiness of food environments?'.

\section{Purpose, scope and outline of the paper}

The purpose of this paper is twofold: (i) to review evidence on the links between trade agreements, food environments and diet quality; and (ii) based on the key trade-related 
Table 1 Glossary of trade policy terminology and definitions, adapted from Thow (71)

Term Definition

Foreign direct investment (FDI)

General Agreement on Trade in Services (GATS)

General Agreement on Tariffs and Trade (GATT)

Import licensing

Most favoured nation (MFN)

Non-discrimination

National treatment (NT)

Non-tariff barriers to trade (NTBT)

Policy space

Policy capacity

Quota

Sanitary and

phytosanitary (SPS)

measures

Subsidy

Tariffs, applied tariffs/rates, and bound tariffs/rates

Tarrification

Tariff escalation

Tariff rate quota (TRQ)

Technical Barriers to Trade (TBT)

Trade agreement

Trade liberalization

TRIMs

TRIPS

World Trade Organization (WTO)
An investment in a country other than that of the investor, involving a long-term relationship and substantial, but not necessarily majority, interest in an enterprise by the investor. Foreign direct investment can take place through direct entry or investment in existing firms.

WTO agreement governing services trade. Requires member countries to provide national treatment to foreign service provides in those service industries that they have agreed to liberalize under GATS.

Multilateral FTA first signed in 1947 between 23 countries. Superceded by the WTO in 1995. Updated GATT (1994) is now one of the WTO's agreements.

Controls imposed by the state on importers.

WTO principle of not discriminating between one's trading partners.

The practice of not making a distinction in favour of or against certain trading partners, or between imported and domestically produced goods, once goods have entered the market. A critical component of the MFN and NT principles Foreign goods or committed services covered by a trade treaty must be treated the same as the identical or 'like' domestic good or service.

The principle of giving foreign firms 'no less favourable' treatment than domestic firms/goods once border measures have been applied. Internal tax and regulatory measures must be applied equally to imported and domestic goods or committed (scheduled) services in order to avoid trade disputes.

Government measures other than tariffs that restrict trade flows (e.g. quantitative restrictions on goods or services, import licensing, variable levies, import barriers and TBTs.

The freedom, scope and mechanisms that governments have to choose, design and implement public policies to fulfil their aims.

The fiscal ability (resources) of states to enact those policies or regulations, which depends upon their ability to capture sufficient revenue through taxation for this purpose.

A quantitative restriction that limits the number or volume of foreign products that can enter a domestic market.

Technical barriers designed for the protection of human health or the control of animal and plant pests and diseases

A direct or indirect benefit/incentive granted by a government for the production or distribution (including export) of a good. There are two main types of subsidy: export-contingent and domestic (not directly linked to exports).

An applied tariff/rate is a custom duty (tax) applied on imported goods at the border. Tariffs are levied either on an ad valorem basis (percentage of value) or on a specific basis (e.g. by weight or volume). Bound tariffs/rates are enforceable and are the highest rate that a WTO member country can charge on imports without attracting an appeal for compensation by the affected country. For this reason, tariffs/rates actually applied on imports are typically lower than bound tariffs/rates.

The replacement of non-tariff measures such as quotas with approximately equivalent tariffs.

Higher import duties imposed on processed and semi-processed foods than on raw materials, protecting domestic industries and discouraging the development of processing activities in the countries where raw materials originate.

Application of a higher tariff rate to imported goods after a certain quantitative limit (quota) has been reached. An increase in a TRQ therefore increases the volumes of goods that can be imported at the lower in-tariff quota rate, thereby facilitating trade.

Non-tariff regulations, standards, testing and certification procedures, which can create obstacles to trade. WTO member countries agreed to the use of disciplinary measures against TBTs on both industrial and agricultural products as part of the Uruguay Round of multilateral trade negotiations (1986-1993).

A negotiated agreement between two or more countries to limit or alter their policies with respect to trade. Trade agreements can be bilateral, regional or multilateral.

The reduction or removal of barriers to trade in order to create a 'free' market in goods, services or finance. A political philosophy that supports a reduced government role in the economy.

The WTO's Agreement on Trade-Related Investment Measures, which requires member countries to phase out (and refrain from implementing) trade distorting or restricting investment measures that are inconsistent with GATT principles. The WTO's Agreement on Trade-Related Aspects of Intellectual Property Rights which stipulates minimum standards of intellectual property protection.

Replaced the GATT in 1995 as the legal and institutional foundation of the multilateral trading system of member countries following the Uruguay Round 


\section{Box 1 Food and agriculture-related World Trade Organization (WTO) trade agreements}

i. Agreement on Agriculture (AoA)

ii. Agreement on the Application of Sanitary and Phytosanitary (SPS) measures

iii. Agreement on Trade-Related Aspects of Intellectual Property Rights (TRIPS)

iv. Technical Barriers to Trade (TBT) Agreement

v. Dispute Settlement Understanding

vi. General Agreement on Trade in Services (GATS)

vii. Agreement on Trade-Related Investment Measures (TRIMS)

viii. Agreement on Government Procurement (AGP)

obesity/NCD issues identified through the review, propose a framework for monitoring the potential and actual impacts of trade agreements on national food environments from an obesity/NCD perspective.

The theoretical framework underpinning both the evidence review and the proposed monitoring framework is what Lang and Rayner call 'ecological public health' (25). It brings together a range of macroeconomic, social, environmental, psychological and nutrition-based theories, which have been developed over a number of years to explain the development of communicable and NCDs (25). Conceptually, food-related trade and investment is one of many influences on food environments and diets. Trade tends to operate indirectly through complex and synergistic interactions along the whole food supply chain, from production, processing, distribution and retail of foods, with subsequent impacts on food availability, nutritional quality, price and promotion at the national level (see Fig. 1). Trade can also affect diet and health via indirect pathways (not shown in Fig. 1) (e.g. via income distribution).

For practical purposes, the scope of the evidence review and the proposed monitoring framework is limited to the impacts of trade agreements (multilateral, regional and bilateral) on food systems and food environments at the country level. The focus is on the direct impacts of trade policy-making processes and trade agreement provisions on the production, processing, distribution and retail of foods, and subsequently on food availability, nutritional quality, price and promotion at the national level. Indirect pathways from trade through the social determinants of diets and health are not considered. Similarly, domestic policy measures not typically addressed within trade agreements but which are trade-related (such as currency devaluation) are not included. There is, however, scope for these to be incorporated into the framework at a later date.

\section{Review of the evidence linking trade agreements and food environments}

Evidence on the links between trade agreements and food environments from an obesity/NCD perspective was identified through a search of the following medical and social science databases in January 2013: Google Scholar, Medline, Social Sciences Citation Index and EconLIT. The review was limited to studies that have either (i) developed approaches, methods or indicators to monitor the impacts of trade agreements on food environments from an obesity/ NCD perspective; (ii) examined the impacts of trade agreements on food chains and at least one indicator of the food environment (food availability, price, nutritional quality or promotion) or (iii) conceptualized the links between trade liberalization, food chains and food environments from an obesity/NCD perspective. A combination of the search terms ('trade agreement' or 'trade in goods' or 'trade in services' or 'foreign direct investment' or 'trade governance' or 'trade liberalisation') and ('food' or 'food environment' or 'diet') and ('obesity' or 'non-communicable disease' or 'chronic disease') and ('monitoring' or 'evaluation' or 'impact') was used. Studies that did not take an explicit obesity/NCD or nutrition transition perspective, and studies that examined domestic policy measures to alleviate the impact of trade agreements on food environments (such as import bans and taxes on unhealthy foods and drinks) were excluded. The review was limited to studies published between 1990 and 2013 in the English language and in peer-reviewed journals.

A total of nine studies were identified that met the search criteria. Three studies examined the diet impacts of specific trade agreements, and focused on two major RTAs in the Americas region: the Central America-Dominican Republic FTA (CAFTA-DR) and the North American Free Trade Agreement (NAFTA) $(18,26,27)$. A further six studies were identified, which examined trade liberalization processes and impacts on food environments and diets more broadly, with a particular focus on the Pacific Island countries where trade liberalization has played a substantial role in the nutrition transition (28-33). No studies were identified, which used methods or indicators to systematically monitor trade agreements through an obesity/NCD lens. Indeed, there appears to be no systematic monitoring of new and existing trade agreements from any health perspective.

\section{Specific trade agreements, food chains and food environments}

The three studies that examined the potential impacts of the NAFTA and CAFTA-DR on diets determined that provisions included in these agreements to reduce tariff and non-tariff barriers to trade, facilitate more favourable 


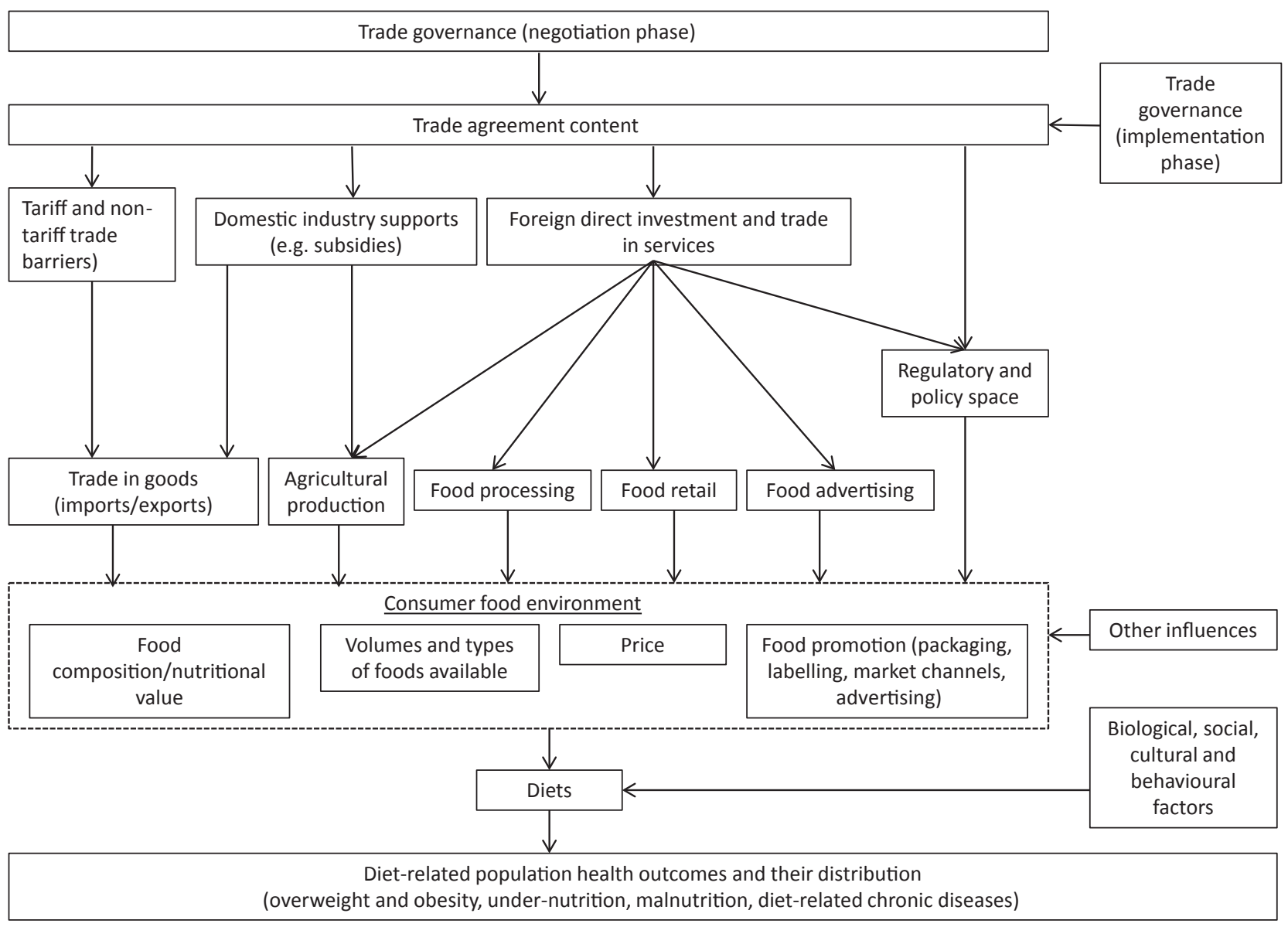

Figure 1 Conceptual framework for the direct links between trade agreements, food environments, diets and obesity/non-communicable diseases outcomes. Adapted from Hawkes (p. 37) (72).

investment climates, and change the nature of domestic protections and supports in low- and middle-income countries (LMICs) were likely to increase availability and lower relative retail prices of animal products (meats and dairy), animal feed grains and highly processed foods and their ingredients $(26,27)$. Provisions contained within the CAFTA-DR, which stipulated the phased reduction and/or elimination of tariff and non-tariff barriers on poultry and pork meat, processed meats, dairy products and some other processed foods and processed food ingredients, for example, were predicted to increase the availability and lower the relative retail prices of these food products and ingredients in the Central American countries (26). Provisions facilitating more favourable investment climates in these countries were also predicted to increase domestic meat and processed food production in these countries (26). Similarly, imports of animal feed grains, soybeans, sugars derived from corn (including highfructose corn syrup), processed 'ready-to-eat' snack foods, dairy and meat products from the United States into Mexico increased following the signing of the NAFTA and the lowering of barriers to trade between the United States and Mexico (27). Inward FDI into Mexico by US-based food and drink manufacturing companies, and domestic meat production within Mexico was also found to have increased significantly in the two decades following the signing of the NAFTA (27).

\section{Trade and investment liberalization, food chains and food environments}

Increased investment by TFCs in the domestic food processing and retail sectors of LMICs, as well as associated IP concerns relating to food labelling and advertising, have become increasingly salient issues for public health nutrition (1). Indeed, there is evidence of a strong link between inward FDI, the expansion of highly processed food chains, and retail sales and consumption of these products in LMICs $(18,31,34)$. FDI by TFCs stimulates competition and alters the food supply as a whole, creates a cultural identity for new foods and introduces new ways to sell and promote them (22). Liberalizing trade in services and 
investment also facilitates the transnational growth and reach of advertising services, which can affect how consumers, including children, perceive choices they make about food consumption. Relative to trade in goods, FDI can be a highly cost-effective way for TFCs to reach foreign markets, enabling them to 'jump' trade barriers and optimize the effectiveness of branding and promotional marketing (34). FDI also offers the potential to catapult a company into the position of market leader, and facilitates the ability of TFCs to tailor the entire production, marketing and distribution process to local tastes and conditions (34). Processed foods are particularly well suited to this, with significantly greater scope for value-adding and market segmentation (32).

A recent economic modelling study demonstrated that liberalization of FDI through trade agreements with the United States significantly increased the amount of soft drinks consumed within signatory LMICs, and consequently increased the risk of NCDs, particularly diabetes (33). The implications of greater investment by US-based TFCs in Vietnam following Vietnam's WTO accession and the lifting of trade restrictions by the United States are highlighted in Box 2.

Of key concern in the Pacific region has been the increasing import volumes of vegetable oils, margarine, butter, meat and chickens and canned meat alongside rising saturated fat intakes (28-31). For example, between 1963 and 2000, total fat supply increased in some Pacific Island countries by as much as $80 \%(35)$.

\section{Other relevant literature}

While not meeting the original search criteria, a number of important insights were identified in the broader literature on trade-related policies, diets and health.

\section{Changes in domestic protections and supports}

Direct agricultural production or export subsidies are prohibited by the WTO under the Agreement on Subsidies and Countervailing Measures. However, domestic agricultural support measures within high-income countries such as the United States, including subsidies designed to promote exports, are widely believed to have caused major distortion in global agricultural markets. Schoonover and Muller's (2006) analysis of the US Farm Bill, the primary instrument through which domestic support is granted to the US agricultural sector, found that domestic support to corn and soybeans has driven down the price of these products while the prices of fruits and vegetables, grown without such subsidies, have steadily increased (36).

The Agreement on Agriculture (AoA) provides scope for countries to implement their agricultural tariff reduction commitments in a manner which can provide incentives

\section{Box 2 Foreign direct investment by US-based transnational food companies in Vietnam following World Trade Organization (WTO) accession and the lifting of trade restrictions by the US Government}

In 2006, the US Congress passed a bill granting permanent normal trade relations to Vietnam (64). Passage of the legislation was required for US businesses to take full advantage of Vietnam's accession to the World Trade Organization (WTO) at the end of 2006.

The opportunities for investment in food supplies had already been taken up by the major multinationals:

- In 1995, Coca-Cola Indochina set up joint enterprises with local company Vinafimex, scattered regionally around the country. In October 1998, the government of Vietnam allowed joint ventures to become $100 \%$ foreign-owned enterprises and the joint ventures were all merged into Coca-Cola Indochina (65).

- US-based quick-service restaurant chain Yum! Brands (Kentucky Fried Chicken, Taco Bell, Pizza Hut) opened franchise stores in the early 2000s, and showed compound annual growth of $54 \%$ over the period 2005-2010 (66).

- In August 2010, PepsiCo announced it was investing US\$250 million into business in Vietnam over 3 years. By the end of 2012, it had opened six beverage production plants, to make carbonated and noncarbonated beverages such as Pepsi, 7Up, Sting, Mirinda, Twister and Aquafina purified water (67).

- Starbucks opened its first store in Vietnam, in Ho Chi Minh City, in February 2013. It is run by Maxim Group, which already has license deals with Starbucks in Hong Kong and Macau (68).

- Also in early 2013, Dunkin' Donuts signed a franchise agreement to develop the brand in Vietnam. The franchise will be supported by local partner Vietnam Food and Beverage Co, and the first store will open in Ho Chi Minh City (66).

- US ice cream brand Baskin-Robbins entered Vietnam in 2012 via a franchise with a local food company, Blue Star Food Corporation, and by the end of the year had 16 stores open and plans for a further 34 (69). Euromonitor estimated Vietnam's ice cream market at US\$65.9 million in 2011 with volume sales of nearly 22,000 tonnes of ice cream, up 5.6\% from the year before (70).

either to restrict the imports of selected products through higher tariffs on these products, or to encourage the imports of desirable products through steeper cuts, which would result in lower tariff levels (37). Often, LMICs try 
not to reduce high tariff levels, either as a strategy to protect domestic markets from competition against cheaper imports or because of the heavy dependence of some LMICs on revenue generated from import duties (38).

Tariffs and domestic subsidies can play an important role in the income-earning capacity of communities in both high-income countries and LMICs, thus affecting food affordability. Staple crop production responds to both export promotion and import substitution measures. In the Pacific Island countries, increased support for production of export crops has resulted in a shift in agricultural land use away from traditional crops (particularly staple grains) towards 'cash crops' typically grown for export (such as refined cereals and vegetable oils) (31).

\section{Trade agreements, governance and policy space}

The trade policy-making process determines whose interests are taken into account and prioritized in the negotiation and implementation of trade agreements, the degree of inclusiveness and transparency (and therefore accountability) involved, as well as the nature and scope of provisions included in a final agreement. New generation trade agreements in particular are believed to have the potential to undermine the creation of a transparent multilateral trade system because the negotiation process is frequently conducted 'behind closed doors' $(39,40)$.

'Policy space' is a term used to describe 'the freedom, scope and mechanisms that governments have to choose, design and implement public policies to fulfil their aims $(41,42)$. The nature and scope of provisions that end up in trade agreements may enable, constrain or undermine policy space and institutional capacity. There has been evidence of negative impacts of trade agreements on policy space and institutional capacity since the establishment of the WTO (43). For example, the Technical Barriers to Agreement Trade (Agreement TBT), which seeks to ensure as few trade restrictive measures relating to food products as possible, has important implications for governments' ability to regulate food marketing and labelling of processed foods. Thailand's proposal to introduce a front-ofpack traffic light labelling system on snack food products on public health grounds in 2006, for example, led the United States to claim that it contravened the TBT and had the potential to distort trade in these products (44).

The intensification of 'behind-the-border' provisions in new generation bilateral and RTAs has the potential to further 'shrink' domestic policy space to a much greater extent than WTO trade rules $(7,42)$. One way in which this manifests is through the increasing dominance of investment and investor rights concerns in trade agreements versus greater constraint on domestic policy options and hence opportunities for governments to pursue nutrition and health goals. RTAs increasingly include measures that constrain or prohibit national governments from introducing domestic regulations or policies, which could be used to promote and protect public health but which are deemed to be 'trade-related', such as food standards, food composition criteria, food labelling, and reductions in food marketing to children (42). As such, many RTAs such as the NAFTA, the CAFTA and potentially the Trans Pacific Partnership (TPP) agreement (which remains under negotiation) have made it more difficult to introduce the exceptions for measures 'necessary to protect human, animal or plant life and health' available through the General Agreement on Trade in Services (GATS). In addition, some of the policy space available with respect to IP rights under the Agreement on Trade-Related Aspects of Intellectual Property Rights (TRIPS) has been challenged in RTAs, potentially constraining governments' ability to regulate food advertising, especially that of processed food products, on the basis of ensuring the protection of trademarks in food advertising.

\section{Impact assessment tools}

Health impact assessment (HIA) of new trade agreements has been advocated (45), and HIAs are sometimes incorporated as part of Environmental Impact Assessments (EIAs), which are mandatory in a number of countries (including the United States and countries of the European Union) for all new trade agreements. Sustainability impact assessments of trade agreements are now regularly conducted in the European Union, and a number of gender, social and human rights-oriented trade impact assessments have been conducted (46-51). These trade impact assessment tools offer insights to inform the development of the INFORMAS monitoring approach. However, with the exception of EIAs in a handful of countries, trade impact assessments are not systematically undertaken or reported, and are not themselves monitoring approaches.

\section{Summary of the evidence base}

The findings from the evidence review are summarized in Table 2. Trade agreements influence food environments through three main pathways: Impacts on (i) trade in goods (import and export flows), (ii) trade in services and FDI, and (iii) domestic protections and supports. The liberalization of trade in goods has been consistently shown to increase total food imports, and particularly import volumes of animal products and highly processed foods in LMICs $(1,5,18,32)$. Particular food categories of concern from an obesity/NCD perspective are processed and fatty meats, edible oils and ultra-processed snack foods. Indirectly, liberalization of investment and trade in services opens countries to investments in production, processing, retailing and advertising, and has been found to expand 
Table 2 Summary of evidence on the links between trade liberalization, trade agreements and food environments from an obesity/non-communicable diseases perspective

\begin{tabular}{lll}
\hline $\begin{array}{l}\text { Trade liberalization measures and trade } \\
\text { agreement provisions identified }\end{array}$ & $\begin{array}{l}\text { Aspects of food environments affected or likely } \\
\text { to be affected }\end{array}$ & Food categories affected \\
\hline
\end{tabular}

Facilitation of trade in goods

- Reduction or elimination of tariffs

- Reduction or elimination of non-tariff barriers (increased tariff-rate quotas, removal of technical barriers to trade, harmonization of SPS measures)

- Tarrification

- Removal of import licensing systems

- Elimination of price banding mechanisms

Facilitation of trade in services and foreign direct investment (FDI)

Promotion of more favourable investment climates through:

- Granting of equal rights to foreign and domestic investors

- Greater protection of IP rights (including trademarks and patents, minimum protection standards for brands, new enforcement and dispute settlement mechanisms)

- Domestic policy changes, including removal of or reduced restrictions on foreign ownership, prohibition of performance requirements for foreign investors (such as minimum amount of domestic content in production), prohibition of new laws which would change status of foreign investments once established

- Facilitation of tourism and flows of people across borders

- Liberalization of trade in communications and other services
- Increased FDI in agricultural production, processing and retail sectors (especially highly processed food chains), as well as advertising and communications sectors

- Increased domestic livestock production

- Lower retail food prices, especially for highly processed foods

- Increased presence of foreign brands

- Expansion of domestic food processing and retail sectors (dominated by transnational supermarket, convenience store and fast food chains), opening up new sales channels for highly processed foods

- Consolidation of food processing and retail sectors

- Changes within food supply chains favouring larger-scale supply, procurement and distribution

- Increased availability, advertisement and awareness of high-profit margin, novel highly processed foods

- More aggressive, comprehensive and targeted marketing of processed foods, particularly towards children and young people

- Tailoring of product development and marketing to appeal to local tastes

- Increases in retail sales and consumption of highly processed foods

Restrictions on domestic protections and supports

- Removal of agricultural safeguard measures

- Restrictions on exemption of sensitive products

- Restrictions on use of anti-dumping measures

- Reduced domestic agricultural supports and export subsidies for subsistence crops

- Increased agricultural and export promotion measures for cash crops and livestock

Shift in production from subsistence crops to cash crops, livestock production and higher profit margin commodities and foods for export
- Increased or accelerated rate of increase in food imports overall, particularly for animal products, staple commodities (especially corn and soybean), animal feed grains and

- Increase in domestic meat production due to increased availability and lower prices of animal feed grains

- Expansion of processed foods sectors

- Increased availability of, and lower retail prices for, meats and highly processed foods including new, non-traditional foods

- Increase in total volume of food available for consumption

- Increased consumption of animal products and highly processed foods highly processed foods

- Meat (especially poultry and pork)

- Grains for animal feed (especially soybean and yellow corn)

- Processed foods and their ingredients, including soft drinks, savoury and sweet snacks, breakfast cereals, sauces, (e.g. ketchup and mayonnaise), confectionary, processed deli meats, processed dairy products (e.g. processed cheese, ice cream and whey used as an ingredient in animal feed), sweeteners derived from corn including high-fructose corn syrup

- Edible oils (especially soybean, palm and canola/rape), including hydrogenated oils used as ingredients in processed foods

- Refined grains (e.g. rice, white corn)

- Fresh and processed fruits

- Processed vegetables (especially french fries)

- Highly processed foods and their ingredients, including soft drinks, snacks, baked goods, frozen and dairy desserts, packaged breakfast cereals, fast foods, ready meals, dressings and sauces, confectionary, processed meats, processed dairy, and corn and sugar-based sweeteners

- Animal products (meat, dairy)

\footnotetext{
- Staple root crops and grains (reduced production) consumption)
} 
highly processed food sectors in particular. The selective granting of domestic support measures significantly influences investment decisions by domestic and foreign companies, and the production, price, availability, and consumption of specific foods.

A fourth aspect of trade liberalization - governance and policy space - is of critical importance to monitoring the impacts of trade agreements from an obesity/NCD perspective because it determines whose interests are taken into account and prioritized in the negotiation and implementation of trade agreements, levels of inclusiveness and transparency (and therefore accountability), the nature and scope of provisions included in a final agreement, and the extent to which a trade agreement may enable, constrain or undermine policy space and institutional capacity.

\section{An analytic framework for obesity and NCD-focused monitoring of trade agreements}

The evidence provides a compelling argument for the integration of nutrition concerns into trade policy, and highlights four key issues or domains that could form the basis of the monitoring framework. An evidence-informed approach to monitoring the impact of trade agreements on food environments is proposed below.

\section{Guiding principles and considerations for implementing the monitoring framework}

The monitoring framework proposed in this paper is underpinned by a set of guiding principles developed in accordance with the key principles of INFORMAS (24). Thus, it is designed to be conducted, ideally, in the context of a multi-level food environment monitoring framework, and shares links with other INFORMAS modules, particularly the food retail, food marketing, food price and food composition modules (52-59). It also recognizes the critical importance of advocacy and support activities for policies and actions within the public and private sectors aimed at addressing the issues identified in this paper, and by other INFORMAS modules. It is a step-wise monitoring framework ('minimal', 'expanded' and 'optimal' approaches), including measurement indicators for each approach. The appropriate monitoring approach adopted by participating countries will be determined by available resources and capacity.

\section{Contextual analysis}

It is expected that all countries involved in the INFORMAS monitoring system will undertake a contextual analysis at baseline. This contextual analysis should include an assessment of the national food environment using tools such as those developed by other INFORMAS modules, as well as current population dietary intake patterns and government recommended dietary guidelines. From a trade perspective, additional contextual information would include, at a minimum, the documentation of relevant features of the national policy environment including the country's status in relation to the WTO. A catalogue should be created of all trade agreements that have been ratified, are currently being developed, or are under negotiation. For each agreement, the form (multilateral, regional, bilateral or bilateral investment treaty), partner countries listed and length of time since ratification (or stage of development/ negotiation) should be recorded. An expanded contextual analysis would encompass more detail of the text, including the wording and scope of key provisions. Relevant findings from any previous trade-related assessments could also be identified at this stage.

\section{'Focus' food categories}

For practical purposes and to minimize data collection and analysis burden, countries collecting data for the indicators within the 'minimal' approach may choose to concentrate on a set of selected food categories rather than total food supply. Suggested food categories on which to focus have been identified from the literature reviewed in this paper, and are provided in Box 3 as a guide. Together, these food categories encompass a balance of healthy foods and ultraprocessed, energy-dense and/or high-fat foods; the availability and consumption of which have been consistently shown to increase obesity/NCD risks (60-62). The particular 'focus' food categories selected will necessarily depend on the nature of an individual country's food supply and that particular country's stage in the nutrition transition, as well as, where relevant, the nature and content of the particular trade agreement. Ideally, the impacts of trade agreements on supply of all foods would be monitored and countries that are in a position to do so (i.e. where sufficient data, resources and capacity are available) should collect data on all food categories. The expanded monitoring approach is therefore designed to capture a picture of the impacts of trade agreements on food environments as a whole. The 'optimal' indicators are designed to build on the 'minimal' and 'expanded' indicators by capturing a picture of the impacts of a trade agreement on food availability, prices and consumption.

\section{Ex post monitoring and ex ante assessment}

A key focus of a trade and food monitoring system is monitoring the impact of existing trade agreements on the food environment (this is referred to as ex post monitoring). It is recommended that ex post monitoring of ratified agreements be undertaken through data collection at regular intervals and in-country, to enable timely and 


\section{Box 3 Suggested 'focus' food categories}

\section{Healthy Food Categories}

Fresh fruits

Fresh vegetables, including

staple root crops

Pulses, nuts and seeds

Staple whole-grain cereals
Ultra-processed, energy-dense and/or high-fat foods associated with obesity/NCD risks

Edible oils and spreads (including hydrogenated oils used as an ingredient in processed foods)

Fatty meat products (e.g. turkey tails, mutton-flaps, processed meats)

High-fat, processed dairy products (e.g. processed cheese, ice cream)

Energy-dense beverages (e.g. carbonated soft drinks)

Sugars and other caloric sweeteners (including HFCS)

Savoury ready-to-eat snacks and meals (e.g. potato chips, french fries, instant noodles)

Sweet snacks (e.g. biscuits, pastries, confectionary)

Sweet, packaged breakfast cereals appropriate assessment, and to facilitate tracking of impacts on food environments over time. The precise intervals between ex post assessments will vary by country, according to resources and capacity available, and the frequency with which new trade agreements are negotiated; however, it is recommended that these intervals be limited to between one and three years.

Ideally, findings from ex post monitoring would inform the integration of nutrition concerns into the negotiation of new trade agreements, thus allowing inclusion of measures to mitigate adverse implications and enhance benefits for food environments and diets (this process is referred to as ex ante assessment).

\section{Data sources}

Data sources will be country specific. Much of the information relating to ratified trade agreements is available through trade ministries and the WTO online database (stat.wto.org). Other potential data sources include the FAOSTAT, TradeSTAT and ProdSTAT databases, the USDA Foreign Agricultural Service and Economic Research Service, the office of the United States Trade Representative, the UNCTAD Trade Analysis Branch resources, Euromonitor, the UN Commodity Trade (Comtrade) Statistics Database, and the Direction of Trade Statistics (DOTS).

Assessing the potential impact of trade agreements that are under negotiation (ex ante) is more difficult since the negotiations are frequently conducted 'behind closed doors'. Information about the core measures being proposed is usually available from trade ministries, and occasionally leaked draft text is available through trade watch civil society groups such as Public Citizen (http://www.citizen.org).

It is essential that monitoring be undertaken in a transparent and independent manner, with a minimal require- ment being that monitoring should not be undertaken by those directly involved in the trade negotiation and implementation process. Finally, it will be important to pilot the monitoring approach and measurement indicators used in-country to ensure relevance to the local context and to address priority issues.

\section{Proposed measurement indicators}

A set of proposed indicators for inclusion in the monitoring framework are summarized in Table 3 and described below under four framework 'domains' drawn directly from the evidence base: trade in goods; trade in services and FDI; domestic protections and supports; and policy space and governance. These suggested indicators have been developed based on the literature reviewed in this paper, as well as their utility and relevance from both practical data collection and policy perspectives.

\section{Domain 1: trade in goods}

At a minimum, any provisions contained within each trade agreement relating to the removal or elimination of tariff and non-tariff barriers to trade, and the specific food categories likely to be most affected by these changes, should be identified and analyzed (see Table 4 for a list of common chapters and provisions contained within trade agreements, which can be used as a guide). Data should then be collated on import and export volumes (both absolute and rate of change) of focus food categories, as well as actual and bound tariff rates, tariffrate quotas and tariff differentials (if any) for 'focus' food categories. Collecting the 'expanded' indicators will provide a picture of these changes in the whole food supply. Countries in a position to collect the 'optimal' indicators will collect data on retail food prices, sales and consumption rates, either for the focus food categories or more broadly. 
Table 3 Suggested step-wise framework for monitoring the impacts of trade agreements on national food environments

\begin{tabular}{|c|c|}
\hline Domain & 'Minimal' approach \\
\hline 1. Trade in goods & $\begin{array}{l}\text { 1.1. Provisions in text relating to tariff and non-tariff } \\
\text { barriers to trade, including tariff-rate quotas, import } \\
\text { licensing and price-banding) and specific food } \\
\text { categories affected by these provision } \\
\text { 1.2. Total food import volumes } \\
\text { 1.3. Focus food category import volumes } \\
\text { 1.4. Rate of change in total food import volumes } \\
\text { 1.5. Rate of change in focus food category import } \\
\text { volumes } \\
\text { 1.6. Actual and bound tariff rates for focus food } \\
\text { categories } \\
\text { 1.7. Tariff-rate quotas for focus food categories } \\
\text { 1.8. Tariff differential (if any) between healthy and } \\
\text { unhealthy focus food categories }\end{array}$ \\
\hline
\end{tabular}

2. Trade in services and foreign direct investment (FDI)

3. Domestic protections and supports

\subsection{Provisions in text relating to restrictions on} foreign ownership, intellectual property (IP) protection, performance requirements for foreign investors, and national treatment

2.2. Type and country of origin of all foreign-owned TFCs operating in country

2.3. FDI investment in food production, processing, retail and advertising sectors (monetary value) 2.4. Rate of change in total inward FDI in food and related sectors (including communications and advertising)

3.1. Provisions in text relating to domestic protections and supports (e.g. agricultural safeguards, special treatment of agricultural products, anti-dumping and countervailing measures, agricultural supports and export subsidies and promotion)
'Expanded' approach

1.9. Food import volumes, by category

1.10. Rate of change in food import volumes, by category

1.11. Actual and bound tariff rates

for all food categories

1.12. Tariff-rate quotas for all food categories

1.13. Tariff differential (if any) between all healthy and unhealthy focus food categories

2.5. Market share of foreign-owned transnational food corporations (TFCs) in processing and retail sectors

2.6. Size of processed food sector 2.7. Rate of change in size of processed food sector 2.8. Degree of concentration in food processing and retail sectors

3.2. Export subsidies (in focus food categories or more broadly where possible) (monetary value) 3.3. Subsidy differential (if any) between healthy and unhealthy focus food categories

\section{'Optimal' approach}

1.14. Retail food prices (in focus food categories or more broadly where possible) 1.15. Retail food sales (in focus food categories or more broadly where possible) 1.16. Population consumption volumes (in focus food categories or more broadly where possible)
2.9. Domestic production (monetary value) of focus food categories or more broadly where possible 2.10. Changes in domestic policy relating to foreign ownership and investment

\author{
3.4. Change in domestic \\ production volumes (of focus \\ food categories or more \\ broadly where possible) \\ 3.5. Change in export \\ volumes (of focus food \\ categories or more broadly \\ where possible) \\ 4.2. Changes in domestic \\ policy, regulations and \\ guidelines relating to food \\ marketing composition and \\ labelling
}

\author{
4. Policy space and 4.1. Provisions in text relating to domestic policy \\ governance space and governance (including government \\ procurement, enforcement, transparency, dispute \\ settlement and government regulation of food \\ marketing, composition, labelling)
}

\section{Domain 2: trade in services and FDI}

At a minimum, any provisions contained within each trade agreement relating to the facilitation of a more favourable investment climate should be briefly summarized (refer to Table 4 as a guide). The type and country of origin of all TFCs operating within the country should be documented, as well as total inward food FDI (absolute monetary value and rate of change), should be documented. Countries collecting the 'expanded' indicators will be able to monitor the market share of TFCs operating within the domestic food processing and retail sectors, the size of the food processing sector (absolute monetary value and rate of change) and the level of concentration in the food processing and retail sectors. The 'optimal' indicators will enable monitoring of domestic food production volumes (of focus food catego- ries or more broadly where possible) and changes in domestic policy relating to foreign ownership and investment. Countries are also encouraged to monitor the extent and nature of food advertising, particularly of ultra-processed food categories, following the framework set out in the INFORMAS food promotion module (63).

\section{Domain 3: domestic protections and supports}

At a minimum, any provisions relating to domestic protections and supports (including agricultural safeguards, special treatment, anti-dumping and countervailing measures, agricultural supports, and export subsidies and promotion) should be identified. The 'expanded' indicators are designed to monitor changes in export subsidies, while it would be optimal to also identify any changes in actual 
Table 4 List of chapters and associated provisions typically included in trade agreements and which have implications for food environments

\begin{tabular}{|c|c|}
\hline Chapter & Related provisions \\
\hline $\begin{array}{l}\text { Market access for } \\
\text { goods }\end{array}$ & $\begin{array}{l}\text { Affirmation/ratification of agreement on } \\
\text { agriculture } \\
\text { Rules of origin and related matters } \\
\text { Customs/border measures } \\
\text { Tariff reduction/elimination } \\
\text { Quantitative restrictions (e.g. tariff-rate quotas) } \\
\text { National treatment } \\
\text { Exceptions }\end{array}$ \\
\hline $\begin{array}{l}\text { Technical Barriers to } \\
\text { Trade }\end{array}$ & $\begin{array}{l}\text { Affirmation/ratification of WTO SPS and TBT } \\
\text { agreements } \\
\text { Additional sanitary and phytosanitary } \\
\text { commitments }\end{array}$ \\
\hline Trade Remedies & $\begin{array}{l}\text { Use of agricultural safeguards } \\
\text { Sensitive products } \\
\text { Antidumping and countervailing measures }\end{array}$ \\
\hline $\begin{array}{l}\text { Government } \\
\text { procurement }\end{array}$ & $\begin{array}{l}\text { Non-discrimination } \\
\text { Transparency }\end{array}$ \\
\hline $\begin{array}{l}\text { Investment and } \\
\text { cross-border trade } \\
\text { in services }\end{array}$ & $\begin{array}{l}\text { Affirmation/ratification of WTO GATT and GATS } \\
\text { agreements } \\
\text { National treatment } \\
\text { Performance requirements on FDI } \\
\text { Taxation and subsidies } \\
\text { Financial services } \\
\text { Telecommunications } \\
\text { Labour }\end{array}$ \\
\hline $\begin{array}{l}\text { Intellectual property } \\
\text { rights }\end{array}$ & $\begin{array}{l}\text { Affirmation/ratification of TRIPS } \\
\text { National treatment } \\
\text { Transparency } \\
\text { Trademarks, brands, copyright, patents and } \\
\text { related matters }\end{array}$ \\
\hline Institutional provisions & $\begin{array}{l}\text { Enforcement } \\
\text { Dispute settlement } \\
\text { Transparency }\end{array}$ \\
\hline
\end{tabular}

production and export volumes (of focus food categories or more broadly where possible).

\section{Domain 4: policy space and governance}

At a minimum, it will be important to identify the presence of provisions within each trade agreement, which have the potential to restrict domestic policy space relating to regulation of food marketing, composition and labelling (such as those pertaining to TBTs or IP rights), as well as the existence of an investor state dispute settlement clause, which allows companies to sue governments if their actions are perceived to contravene investor privileges. It would be optimal for any changes to government regulation of food marketing, composition and labelling to be measured.

Figure 2 illustrates how, collectively, the four domains of the proposed monitoring framework can help assess, on an ongoing basis, the impacts of trade agreements on food environments and, ultimately, dietary habits, obesity and NCD risks.

\section{Concluding remarks}

If potential impacts on nutrition and obesity risk are not taken into account and adjustments made accordingly, the proliferation of preferential trade and investment agreements is likely to exacerbate the global burden of NCDs and its inequitable distribution. The proposed monitoring system provides countries with a tool to assess the impacts of existing trade agreements, as well as potential impact of trade agreements under negotiation, on food environments. This will assist countries in identifying trade and non-trade policy measures to mediate adverse effects and maximize positive effects of these agreements on food environments, diets and health.

\section{Acknowledgements}

The Rockefeller Foundation kindly supported the work of INFORMAS by hosting the first formal meeting of INFORMAS at the Rockefeller Foundation Bellagio Centre, Italy from 19 to 23 November 2012. The following organizations provided funding support for the travel of participants to Italy for this meeting and the preparation of background research papers: The Rockefeller Foundation, International Obesity Taskforce (IOTF), University of Auckland, Deakin University, The George Institute, University of Sydney, Queensland University of Technology, University of Oxford, University of Pennsylvania Perelman School of Medicine, World Cancer Research Fund International, University of Toronto, and The Australian National University. The authors would like to thank Francesco Branca and Godfrey Xuereb from the World Health Organization, and Janice Albert from the Food and Agriculture Organization for their participation in the first formal meeting of INFORMAS, and for their input into this paper. The Faculty of Health at Deakin University kindly supported the costs for open access availability of this paper, and the Australian National Health and Medical Research Council Centre for Research Excellence in Obesity Policy and Food Systems (APP1041020) supported the coordination and finalizing of INFORMAS manuscripts.

\section{Conflicts of interest}

Bruce Neal is the Chair of the Australian Division of World Action on Salt and Health (2007-ongoing), was a Member of the Pepsico Global Scientific Advisory Board (20102012), was the Independent Adjudicator for the Australian Responsible Marketing to Children's Initiative (20092010) and holds funding from the Australian Food and Grocery Council as part of a National Health and Medical 


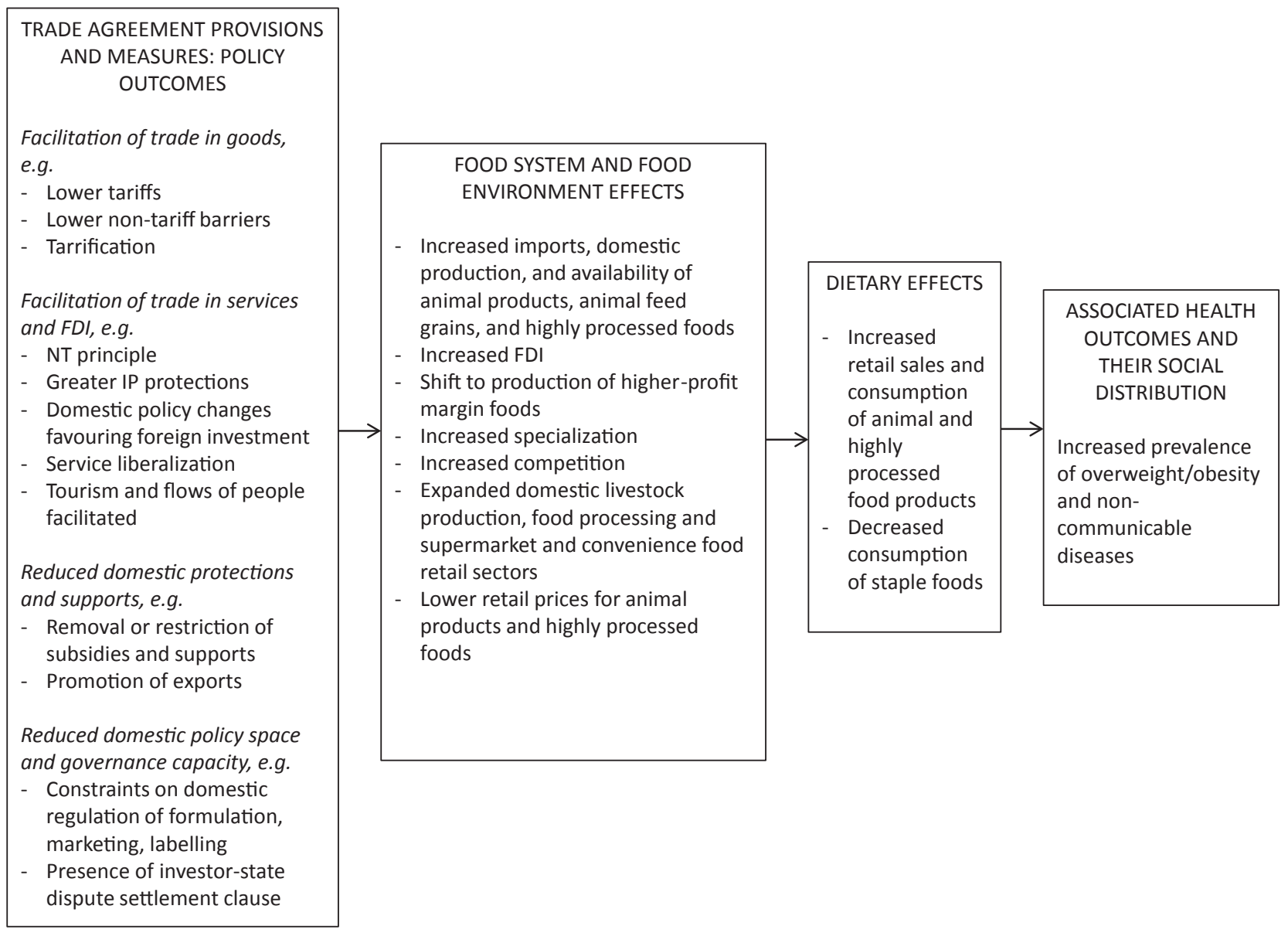

Figure 2 Evidence-informed elements of a trade-food environments-obesity/non-communicable diseases risks monitoring framework.

Research Council of Australia Partnership project (20102014). The other authors declare that they have no competing interests.

\section{References}

1. Hawkes C, Chopra M, Friel S. Globalization, trade and the nutrition transition. In: Labonte R, Schrecker T, Packer C, Runnels V (eds). Globalization and Health: Pathways, Evidence and Policy. Routledge: New York, 2009, pp. 235-262.

2. Lock K, Stuckler S, Charlesworth K, McKee M. Rising global food prices: potential causes and health impacts. BMJ 2009; 339 : 269-272.

3. FAO. The State of Food Insecurity in the World 2008: High Food Prices and Food Security - Threats and Opportunities. Food and Agriculture Organization of the United Nations: Rome, 2008.

4. Friel S, Baker P. Equity, food security and health equity in the Asia Pacific Region. Asia Pac J Clin Nutr 2009; 18: 620-632.

5. Blouin C, Chopra M, van der Hoeven R. Trade and social determinants of health. Lancet 2009; 373: 502-507.

6. Hawkes C, Murphy S. An overview of global food trade. In: Hawkes C, Blouin C, Henson S, Drager N, Dube L (eds). Trade, Food, Diet and Health: Perspectives and Policy Options. Chichester. John Wiley \& Sons Ltd: West Sussex, 2010, pp. 16-34.
7. Chauffour J, Maur J. Beyond market access. In: Chauffour J, Maur J (eds). Preferential Trade Agreement Policies for Development: A Handbook. The International Bank for Reconstruction and Development/The World Bank: Washington DC, 2011, pp. $17-36$.

8. Acharya R, Crawford J, Maliszewska M, Renard C. Landscape. In: Chauffour J, Maur J (eds). Preferential Trade Agreements Policies for Development: A handbook. The International Bank for Reconstruction and Development/The World Bank: Washington DC, 2011, pp. 37-68.

9. United Nations Economic and Social Commission for Asia and the Pacific (UNESCAP). Asia-Pacific Trade and Investment Report 2011: Post-Crisis Trade and Investment Opportunities. United Nations Economic and Social Commission for Asia and the Pacific: Bangkok, 2011.

10. Baldwin R. 21st century regionalism: filling the gap between 21st century and 20th century trade rules. Policy Insights 2011 No.56. Geneva: Centre for Economic Policy Research, 2011.

11. World Bank. World Development Report 2006: Equity and Development. World Bank: Washington, DC, 2005.

12. World Bank. World Development Report 2008: Agriculture for Development. World Bank: Washington, DC, 2008.

13. World Bank. World Development Report 2010: Development and Climate Change. The World Bank: Washington DC, 2010. 
14. Labonte R, Schrecker T, Packer C, Runnels V. Globalization and Health: Pathways, Evidence and Policy. Routledge: New York, 2009.

15. Commission on Social Determinants of Health (CSDH). Closing the gap in a generation: Health Equity through Action on the Social Determinants of Health. Final Report of the Commission on Social Determinants of Health. World Health Organization: Geneva, 2008.

16. Smith RD, Lee K, Drager N. Trade and health: an agenda for action. Lancet 2009; 373: 768-773.

17. Labonte R, Sanger M. Glossary of the World Trade Organization and public health: part 1. J Epidemiol Community Health 2006; 60: 655-661.

18. Thow AM, Hawkes C. The implications of trade liberalization for diet and health: a case study from Central America. Global Health 2009; 5: 5.

19. Friel S, Chiang T, Cho Y et al. Freedom to lead a life we have reason to value? A spotlight on health inequity in the Asia Pacific region. Asia Pac J Clin Nutr 2011; 23 (2): 246-263.

20. Stuckler D. Population causes and consequences of leading chronic diseases: a comparative analysis of prevailing explanations. Milbank Q 2008; 86: 273-326.

21. Rayner G, Hawkes C, Lang T, Bello W. Trade liberalization and the diet transition: a public health response. Health Promot Int 2007; 21(S1): 67-74.

22. Hawkes C. Uneven dietary development: linking the policies and processes of globalization with the nutrition transition, obesity and diet-related chronic diseases. Global Health 2006; 2 : 4.

23. Hawkes C, Chopra M, Friel S, Lang T, Thow A. Globalization, Food and Nutrition Transitions. World Health Organization: Geneva, 2005.

24. Swinburn B, Sacks G, Vandevijvere S et al. International Network for Food and Obesity/non-communicable diseases Research, Monitoring and Action Support (INFORMAS): overview and key principles. Obes Rev 2013; 14 (Suppl. 1): 1-12.

25. Lang T, Rayner G. Overcoming policy cacophony on obesity: an ecological public health framework for policymakers. Obes Rev 2007; 8: 165-181.

26. Hawkes C, Thow AM. Implications of the Central AmericaDominican Republic-Free Trade Agreement for the nutrition transition in Central America. Rev Panam Salud Publica 2008; 24 345-360.

27. Clark SE, Hawkes C, Murphy SME, Hansen-Kuhn KA, Wallinga D. Exporting obesity: US farm and trade policy and the transformation of the Mexican consumer food environment. Int $J$ Occup Environ Health 2012; 18: 53-65.

28. Thow A, Snowdon W. The effect of trade and trade policy on diet and health in the Pacific Islands. In: Hawkes C, Blouin C, Henson S, Drager N, Dubé L (eds). Trade, Food, Diet and Health: Perspectives and Policy Options. Wiley Blackwell: Oxford, 2010, pp. 147-168.

29. Legge D, Gleeson D, Snowdon W. Trade Agreements and Non-communicable Diseases in the Pacific Islands. Pacific NCD Forum 2011.

30. Snowdon W, Moodie M, Schultz J, Swinburn B. Modelling of potential food policy interventions in Fiji and Tonga and their impacts on noncommunicable disease mortality. Food Policy 2011; 36: 597-605.

31. Thow A-M, Heywood P, Schultz J, Quested C, Jan S, Colagiurie S. Trade and the nutrition transition: strengthening policy for health in the Pacific. Ecol Food Nutr 2011; 50: 18-42. 32. Thow AM. Trade liberalisation and the nutrition transition: mapping the pathways for public health nutritionists. Public Health Nutr 2009; 12: 2150-2158.
33. Stuckler D, McKee M, Ebrahim S, Basu S. Manufacturing epidemics: the role of global producers in increased consumption of unhealthy commodities including processed foods, alcohol, and tobacco. PLoS Med 2012; 9: 1-8.

34. Hawkes C. The role of foreign direct investment in the nutrition transition. Public Health Nutr 2005; 8: 357-365.

35. Hughes R, Lawrence M. Globalization, food and health in Pacific Island countries. Asia Pac J Clin Nutr 2005; 14: 298-306. 36. Schoonover H, Muller M. Food without thought: How U.S. Farm Policy Contributes to Obesity. Institute for Agriculture and Trade Policy: Minneapolis, MN, 2006.

37. Atkins VJ. Agriculture, trade and obesity prevention. In: Pan American Conference on Obesity, with special attention to Childhood Obesity, June 8-11, 2011; Oranjestad, Aruba.

38. Oxfam. PACER Plus and its alternatives: which way for trade and development in the Pacific? Oxfam briefing paper 2009. Oxfam Australia and Oxfam New Zealand; 2009.

39. Ranald R. The Australia-US Free Trade Agreement: a contest of interests. J Aust Polit Econ 2006; 57: 30-56.

40. Kelsey J. New-generation free trade agreements threaten progressive tobacco and alcohol policies. Addiction 2012; 107: 17191721.

41. Koivusalo M, Schrecker T, Labonte R. Globalization and Policy Space for Health and Social Determinants of Health. University of Ottawa: Ottawa, 2008.

42. Labonte R, Mohindra K, Lencucha R. Framing international trade and chronic disease. Global Health 2011; 7: 21.

43. Gallagher K. Understanding developing country resistance to the Doha Round. Rev Int Polit Econ 2008; 15: 62-85.

44. USTR. 2010 Report on Technical Barriers to Trade. Washington DC: The Office of the United States Trade Representative; 2010 .

45. Lee K, Ingram A, Lock K, McInnes C. Bridging health and foreign policy: the role of health impact assessments. Bull World Health Organ 2007; 85: 207-211.

46. Plummer M, Cheong D, Hamanaka S. Methodology for Impact Assessment of Free Trade Agreements. Asian Development Bank: Manila, Philippines, 2010.

47. George C, Kirkpatrick C. Trade and development: assessing the impact of trade liberalisation on sustainable development. J World Trade 2004; 38: 441-469.

48. European Commission. Handbook for Trade Sustainability Impact Assessment. European Commission: Brussels, 2006.

49. MacLaren B. Free trade agreements in Peru and Colombia: monitoring future impacts from a gender perspective. Ottawa, ON: North-South Institute; 2012.

50. Harrison J. Human rights impact assessments of trade agreements: reflections on practice and principles for future assessments. Background paper for the Expert Seminar on Human Rights Impact Assessments of Trade and Investment Agreements, June 23-24, 2010; Geneva, Switzerland.

51. Lee K, Lock K, Ingram A. The Role of Health Impact Assessment. Nuffield Trust: London, 2006.

52. Kelly B, King L, Baur L et al. Monitoring food and nonalcoholic beverage promotions to children. Obes Rev 2013; 14 (Suppl. 1): 59-69.

53. L'Abbe M, Schermel A, Minaker L et al. Monitoring foods and beverages provided and sold in public sector settings. Obes Rev 2013; 14 (Suppl. 1): 96-107.

54. Lee A, Ni Mhurchu C, Sacks G et al. Monitoring the price and affordability of foods and diets globally. Obes Rev 2013; 14 (Suppl. 1): 82-95.

55. Brinsden $\mathrm{H}$, Lobstein $\mathrm{T}$, Landon $\mathrm{J}$ et al. Monitoring policy and actions on food environments: rationale and outline of the 
INFORMAS policy engagement and communication strategies. Obes Rev 2013; 14 (Suppl. 1): 13-23.

56. Ni Mhurchu C, Vandevijvere S, Waterlander WE et al. Monitoring the availability of healthy and unhealthy foods and nonalcoholic beverages in community and consumer retail food environments globally. Obes Rev 2013; 14 (Suppl. 1): 108-119. 57. Rayner M, Wood AT, Lawrence M et al. Monitoring the health-related labelling of foods and non-alcoholic beverages in retail settings. Obes Rev 2013; 14 (Suppl. 1): 70-81.

58. Sacks G, Swinburn B, Kraak VI et al. A proposed approach to assessing the extent to which the policies and actions of private sector organisations affect food environments and influence obesity/non-communicable diseases prevention efforts. Obes Rev 2013; 14 (Suppl. 1): 38-48.

59. Swinburn B, Vandevijvere S, Kraak VI et al. The government healthy food environment policy index for monitoring and benchmarking government policies and actions to improve the healthiness of food environments. Obes Rev 2013; 14 (Suppl. 1): 24-37. 60. World Health Organization (WHO). Diet, Nutrition and the Prevention of Chronic Diseases. Joint WHO/FAO Expert Consultation. WHO Technical Report Series no. 916. WHO: Geneva, 2003.

61. Lim SS, Vos T, Flaxman AD et al. A comparative risk assessment of burden of disease and injury attributable to 67 risk factors and risk factor clusters in 21 regions, 1990-2010: a systematic analysis for the Global Burden of Disease Study 2010. Lancet 2012; 380: 2224-2260.
62. Popkin B. The nutrition transition and its health implications in low income countries. Public Health Nutr 1998; 1: 5-21.

63. Vandevijvere S, Monteiro C, Krebs-Smith SM et al. Monitoring and benchmarking population diet quality globally: a step-wise approach. Obes Rev 2013; 14 (Suppl. 1): 135-149.

64. Patton D. US passes bill to normalise trade with Vietnam. Food Navigator USA. 2006; 12 December 2006.

65. VietNamNet. How Coca Cola gave Vietnamese partners a boot? VietNamNet. 2013; 10 February, 2013.

66. Whitehead R. Dunkin' to enter Vietnam as part of massive Asia expansion. Food Navigator USA. 2013; 31 January, 2013.

67. Food Navigator USA. PepsiCo inaugurates sixth plant in Vietnam. Food Navigator USA. 2012; 19 March 2012.

68. Warc. Starbucks targets Vietnam. Warc, 4 January 2013.

69. Culliney K. Timely entrance into Vietnam for Baskin Robbins. Food Navigator USA. 2012; 10 January 2012.

70. Euromonitor International. Ice cream in Vietnam. 2013.

71. Thow A. Glossary of trade terms. In: Hawkes C, Blouin C, Henson S, Drager N, Dube L (eds). Trade, Food, Diet, and Health: Perspectives and Policy Options. John Wiley \& Sons Ltd: West Sussex, 2010, pp. 299-300.

72. Hawkes C. The Influence of trade liberalisation and global dietry change: The case of vegetable oils, meat and highly processed food. In: Hawkes C, Blovin C, Henson S, Drager N, Dube L (eds). Trade, Food, Diet, and Health: Perspectives and Policy Options. John Wiley \& Sons Ltd: West Sussex, 2010, p. 37. 